Review

\title{
Review Update on the Life Cycle, Plant-Microbe Interaction, Genomics, Detection and Control Strategies of the Oil Palm Pathogen Ganoderma boninense
}

\author{
Izwan Bharudin 1,2,*(D), Anis Farhan Fatimi Ab Wahab 1,3, Muhammad Asyraff Abd Samad ${ }^{1}, \operatorname{Ng}^{\text {Xin Yie }}{ }^{1}$ (D), \\ Madihah Ahmad Zairun 1,4 , Farah Diba Abu Bakar ${ }^{1}$ and Abdul Munir Abdul Murad ${ }^{1}$
}

1 Department of Biological Sciences and Biotechnology, Faculty of Science and Technology, Universiti Kebangsaan Malaysia, UKM, Bangi 43600, Malaysia; anis.aw@fgvholdings.com (A.F.F.A.W.); P99743@siswa.ukm.edu.my (M.A.A.S.); P108611@siswa.ukm.edu.my (N.X.Y.); madihah@mpob.gov.my (M.A.Z.); fabyff@ukm.edu.my (F.D.A.B.); munir@ukm.edu.my (A.M.A.M.)

2 Fraser's Hill Research Centre (PPBF), Faculty of Science \& Technology, Universiti Kebangsaan Malaysia, UKM, Bangi 43600, Malaysia

3 FGV Innovation Centre (Biotechnology), Pt. 23417 Lengkuk Teknologi, Bandar Enstek 71760, Malaysia

4 Plant Pathology \& Biosecurity Unit, Biology \& Sustainability Research Division, 6, Malaysian Palm Oil Board, Bandar Baru Bangi, Kajang 43000, Malaysia

* Correspondence: ibb@ukm.edu.my

check for updates

Citation: Bharudin, I.; Ab Wahab, A.F.F.; Abd Samad, M.A.; Xin Yie, N.; Zairun, M.A.; Abu Bakar, F.D.; Abdul Murad, A.M. Review Update on the Life Cycle, Plant-Microbe Interaction, Genomics, Detection and Control Strategies of the Oil Palm Pathogen Ganoderma boninense. Biology 2022, 11, 251. https://doi.org/10.3390/ biology11020251

Academic Editors: Maria Doroteia Campos and Maria do Rosário Félix

Received: 31 December 2021

Accepted: 3 February 2022

Published: 6 February 2022

Publisher's Note: MDPI stays neutral with regard to jurisdictional claims in published maps and institutional affiliations.

Copyright: (C) 2022 by the authors. Licensee MDPI, Basel, Switzerland. This article is an open access article distributed under the terms and conditions of the Creative Commons Attribution (CC BY) license (https:// creativecommons.org/licenses/by/ $4.0 /)$.
Simple Summary: Palm oil is one of the main crops produced in Southeast Asia. However, the palm oil plantations within the region were severely affected by the basal stem rot (BSR) disease, caused by Ganoderma boninense. The disease causes substantial economic losses to oil palm producers, especially Indonesia and Malaysia. This review will cover the current knowledge on G. boninense published within the last 10 years.

Abstract: Plant pathogens are key threats to agriculture and global food security, causing various crop diseases that lead to massive economic losses. Palm oil is a commodity export of economic importance in Southeast Asia, especially in Malaysia and Indonesia. However, the sustainability of oil palm plantations and production is threatened by basal stem rot (BSR), a devastating disease predominantly caused by the fungus Ganoderma boninense Pat. In Malaysia, infected trees have been reported in nearly $60 \%$ of plantation areas, and economic losses are estimated to reach up to USD500 million a year. This review covers the current knowledge of the mechanisms utilized by G. boninense during infection and the methods used in the disease management to reduce BSR, including cultural practices, chemical treatments and antagonistic microorganism manipulations. Newer developments arising from multi-omics technologies such as whole-genome sequencing (WGS) and RNA sequencing (RNA-Seq) are also reviewed. Future directions are proposed to increase the understanding of $G$. boninense invasion mechanisms against oil palm. It is hoped that this review can contribute towards an improved disease management and a sustainable oil palm production in this region.

Keywords: basal stem rot; biological control; Ganoderma; fungal pathogen; mating; palm oil; plant-microbe interactions

\section{Introduction}

Oil palm is one of the most important oil-producing crops in the world, as it contributes $\sim 34 \%$ of the world's vegetable oil and fat supply [1]. However, the sustainability of oil palm plantations and palm oil production in Southeast Asia is affected by pests such as the bagworm and the beetles Rhynchophorus ferrugineus and Oryctes rhinoceros [2-4], as well as diseases like upper stem rot (USR) and basal stem rot (BSR), caused by fungi of the genus Ganoderma [5-7]. BSR has by far been the most serious disease of oil palm in Malaysia in 
the last 30 years, with increasing disease incidents and infection rates from 1.5\% in 1995 to $7.4 \%$ in 2017 [8]. Typically, plants infected by the fungus stop producing fruits and die within 2-3 years $[9,10]$. Infected oil palms usually produce lower yields due to the reduced weight of fruit bunches. Economic losses due to stem rot diseases in Malaysia are estimated to reach values of up to USD500 million a year [11].

Multiple species of Ganoderma have been reported to incite BSR disease in oil palm in Southeast Asia, namely Ganoderma boninense, Ganoderma zonatum and Ganoderma miniatocinctum [12]. Amongst these species, G. boninense is the most prominent causal agent of both BSR and USR $[13,14]$. By 2020, the total plantation area affected by BSR is estimated to be around 443,430 ha (equivalent to 65.6 million oil palms). Together, both BSR and USR are the most severe diseases affecting oil palm plantations across Southeast Asia [15], reducing yield, increasing plant mortality and necessitating replanting [11].

Ganoderma is a white-rot fungus that belongs to the family Ganodermataceae and the class Agaricomycetes. As with all members of Basidiomycota, Ganoderma have specialized reproductive spores (or basidiospores) that are important in maintaining the sexual cycle and also serve as the main air dispersal unit. Ganoderma boninense is characterized by large and woody bracket basidiocarps, which typically grow on the trunks of trees and, like all other white-rot fungi, degrade the lignin component in wood (Figure 1).

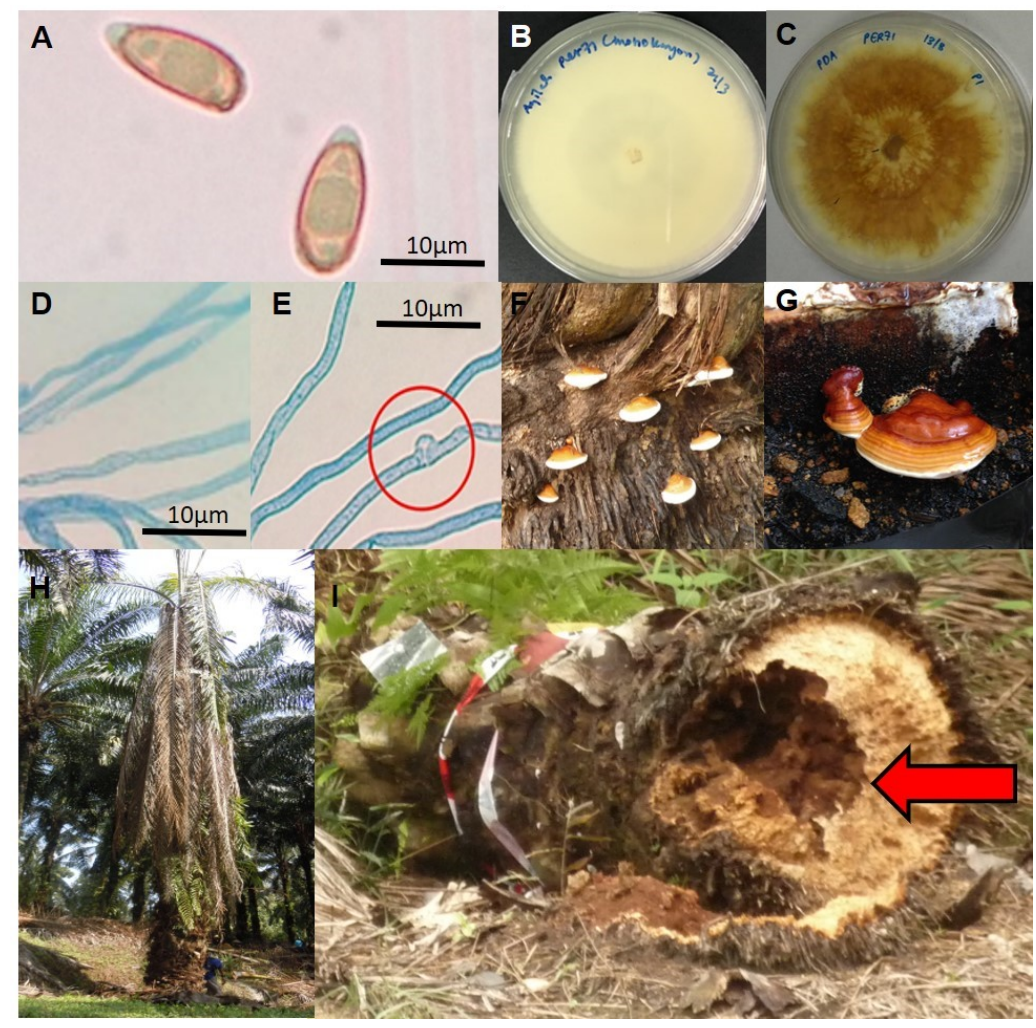

Figure 1. The morphological diversity of G. boninense observed during different life stages. (A) Basidiospore structure observed under the light microscope (100X magnification); (B) Monokaryotic mycelia of G. boninense PER71 grown on Potato Dextrose Agar (PDA) (age 7 days); (C) Dikaryotic mycelia of G. boninense PER71 grown on PDA (age 7 days); (D) Monokaryotic mycelia observed under the light microscope (100X magnification); (E) Dikaryotic mycelia observed under the light microscope (100X magnification) with the presence of a clamp connection in dikaryotic mycelia (red circle); (F) Formation of basidiocarps on the basal stem of the infected oil palm tree; (G) Formation of basidiocarps on rubber wood block (artificial inoculation and formation of G. boninense basidiocarps); (H) The symptoms of BSR disease observed on oil palm trees, such as lower leaves collapsing and hanging downwards vertically from the point of attachment to the trunk; (I) The oil palm trunk falls over due to the decay of the inside basal stem (red arrow). Scale bars: $10 \mu \mathrm{m}(\mathbf{A}, \mathbf{D}, \mathbf{E})$. 


\section{G. boninense Life Cycle}

Basidiomycetes employ two different strategies for reproduction: sexual spores and vegetative mycelia. Although G. boninense possesses both mechanisms of reproduction, basidiospores are believed to be the primary source of inoculum [16], as they are easily dispersed by wind or animal vectors. Once it reaches a suitable environment, the basidiospores germinate to form monokaryotic vegetative mycelia. The monokaryotic mycelia typically grow saprophytically in the environment by feeding on dead plant material. $\mathrm{Nu}-$ clear exchange and migration follow, resulting in the formation of a dikaryotic mycelium, which then invades and establishes itself within the plant host. The dikaryotic mycelia later gives rise to the formation of the fruiting body (Figure 1F) under appropriate environmental conditions. The fruiting body (or basidiocarp) is a multicellular reproductive structure in which karyogamy occurs and meiotic spores are produced. The sexual cycle of Ganoderma sp. is completed once the basidiocarp produces basidiospores (Figure 2). The regulation of sexual reproduction by the tetrapolar mating system promotes outbreeding and the diversity of their genetic content in the same plantation area, thus resulting in dynamic populations, and is most probably the primary cause that leads to inefficient disease management $[16,17]$. The genetic variability was reported to be higher especially for isolates from different geographical origins. Due to the high divergence of the genetic pool between distinct isolates, different strains exhibit a different degree of aggressiveness and tolerance toward biological control and fungicides $[6,17,18]$.

Previous reports have suggested that $G$. boninense is a heterothallic species with bifactorial incompatibility due to their possession of two unlinked mating-type loci, known as mating-type A (matA) and mating-type B (matB) $[19,20]$. Further studies showed that this species has multiple alleles at both mating-type loci, with at least 81 mat $A$ and 83 matB alleles [21]. Studies have also shown that G. boninense requires a compatible partner in order to mate and initiate the sexual cycle-a common feature of heterothallism. Only monokaryons possessing two unlinked mating-type loci are able to initiate the mating pathway and undergo the complete sexual cycle, as ruled by the tetrapolar mating system [18]. The first locus, usually known as matA, is biallelic and harbors genes encoding for homeodomain transcription factors, while the second locus, known as matB, is multiallelic and contains pheromone receptor genes and pheromone precursors [22]. Our initial analyses using the available genomic data indicated that the matA locus of $G$. boninense covers about 360 kilobases in size, and includes genes encoding for both homeodomain transcription factors 1 and 2 (unpublished data), which is similar to those reported in other Ganoderma sp. [23]. In addition, the matB locus of G. boninense contains at least ten pheromone receptors and four pheromone precursors (unpublished data). The mat $B$ genes also play a critical role in mate recognition and choreographs the interactions between prospective mating partners. The initial stage of mating after hyphal fusion begins through the activation of the pheromone response pathway. The activation of the mating pathway is also necessary to override the heterokaryon incompatibility system that is ordinarily triggered when different and genetically distinct hyphae fuse [24]. Other than mate recognition, the $m a t B$ genes are also essential for nuclear migration, septal dissolution and clamp cell fusion [25].

The binding of the pheromones with compatible pheromone receptors activates the transcription of genes related to the mating process through the MAP kinase-mediated signaling cascade [26]. The successful activation of the pheromone response pathway leads to the dissolution of septa and plasmogamy. Thereafter, the mat $A$ genes homeodomain 1 (HD1) and homeodomain 2 (HD2) will serve as the second incompatibility checkpoint. Compatible mating partners bring together the HD1 and HD2 that heterodimerize by polar-hydrophobic interaction, thereby generating an active transcription factor complex that commits mated cells to sexual development [27]. The mat $A$ genes are essential for nuclear pairing, clamp cell formation and coordinating nuclear division and are also involved in clamp cell septation. Both $m a t A$ and matB genes work coordinately to maintain the successfully established dikaryotic stage. In Ustilago maydis, mating-type genes are 
also categorized as virulence factors because they are involved in the activation of other pathogenesis-related genes [28]. Besides, mating is also crucial in ensuring survival and maintaining the genetic variation of many pathogenic fungi.

The mating event provides numerous advantages: it gives rise to novel gene combinations and facilitates the adaptation of the species toward changing environments; it serves to remove mutations that have arisen within the genome as well as increase the efficiency of DNA repair via homologous recombination, in which the second copy of the nucleus will act as a template for DNA repair; and it helps raise the possibility of the fungi establishing better-suited structures and mechanisms for host invasion [29,30], as has been shown in other basidiomycete fungal pathogens, such as Puccinia graminis f. sp. tritici [31] and U. maydis [32].

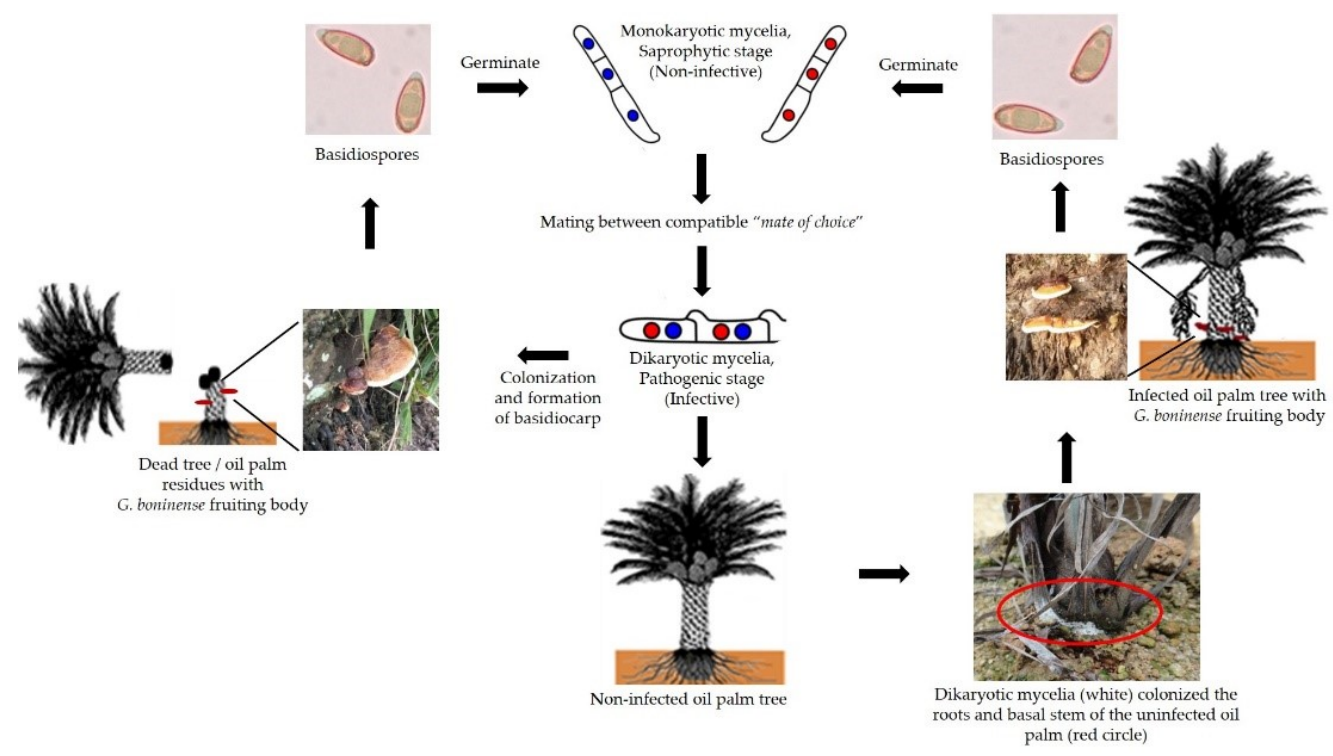

Figure 2. The life cycle of G. boninense. The G. boninense fruiting bodies produce millions of basidiospores which can be spread by numerous vectors, such as wind and animals. The basidiospore germinates to form mycelia (monokaryotic form), which is non-pathogenic to the oil palm tree [33]. The mating between compatible mates of choice (monokaryon/dikaryon) will form the pathogenic dikaryotic mycelia. The dikaryotic mycelia then begins to colonize the root and basal stem of the oil palm tree. Dikaryotic mycelia will undergo hyphae morphogenesis to form a needle-like structure to facilitate the penetration into the host cells. G. boninense infection of the oil palm tree will manifest as the formation of basidiocarps on the basal stem of the infected tree. However, there are cases where the palms dies and collapses in the field without the formation of a G. boninense fruiting body.

\section{Plant-Microbe Interaction}

The mechanism of G. boninense infection of oil palm and its dispersal within oil palm plantations is not fully understood. An earlier study suggested that the colonization of Ganoderma sp. in the oil palm field is achieved through several methods, that include contact between healthy and diseased roots [34]. Colonization by mycelia can also occur on wounded or dead roots. As the oil palm roots can continue to grow beyond four planting rows, this inevitably results in root-to-root contact between palms, enabling the spread of Ganoderma sp. The growing presence of patches due to BSR infection over time has also led to the theory that roots are the primary source of inoculum in the field [35]. Furthermore, oil palm debris that has been colonized by G. boninense mycelia can also act as an inoculum source, thus sustaining the spread of G. boninense even after the replanting of new trees [33].

Management of BSR is difficult and challenging, as the formation of infective dikaryotic mycelia continues through mating between the mycelia and newly germinated basidiospores. The basidiospores can travel long distances through wind and disseminate in the same, or even across different plantation areas $[16,21]$. The fungus then grows along and 
invades the roots through wounds or by puncturing the healthy plant cells [36] through the formation of needle-like structures [37] that eventually penetrate the epidermis layer of the oil palm roots. At advanced stages of infection, the fungal hyphae can be detected in the xylem, phloem, pith and parenchymal cells $[36,38,39]$. The formation of black lines within the infected tissues will lead to the infection in the stem [40]. Under microscopic observation, the black lines are seen as embedded thick-walled, swollen structures of the G. boninense hyphae, which are postulated to play a crucial role in long-term survival in the soil [40] by generating a resistant barrier against other soil microorganisms. Conversely, monokaryotic mycelia remain non-pathogenic due to their incapability of causing damage to-and infecting — the oil palm [41,42].

Being a hemibiotroph, G. boninense is able to switch their lifestyles between biotrophic and necrotrophic phases, depending on the environment and its conditions [36,43]. The fungus exhibits a biotrophic phase during initial stages of infection when hyphae colonize the host plant. The transition to the necrotrophic phase, which involves extensive cell wall degradation, occurs once the pathogen overcomes the host defenses [11,44]. Other pathogenic fungi with similar modes of infection include Botrytis cinerea, Rhizoctonia solani and Sclerotinia sclerotiorum [44,45]. These pathogens produce small cell wall-degrading enzymes (CWDEs), including cellulase, laccase, polygalacturonase and manganese peroxidase, to soften and loosen the host cell wall without detrimentally affecting the host cells [46]. During early infection of the oil palm root, G. boninense hyphae will colonize the roots and secrete trace amounts of CWDEs, including polygalacturonase and laccase [47,48], to enable the establishment of a continued supply of nutrients from the living cells of their hosts. The secreted CWDEs will then degrade the host cell wall and affect the integrity of the cell-wall polysaccharides by triggering the release of damage-associated molecular patterns (DAMP) molecules by the host $[47,49]$. These endogenous danger molecules interact with transmembrane pattern recognition receptors to activate the plant host's primary innate defense response, also known as pathogen-associated molecular pattern-triggered immunity (PTI) [50]. This process initiates the production of several response molecules such as reactive oxygen species (ROS) and phytoalexins, and trigger cell wall alterations and the accumulation of pathogenesis-related (PR) proteins [51,52].

Furthermore, the oil palm also initiates a secondary defense system, known as effectortriggered immunity (ETI), to monitor the presence of effectors secreted by the pathogen [52]. The presence of an effector triggers a hypersensitive response (HR) that will execute programmed cell death (PCD) and other locally induced defense responses to restrict the growth of G. boninense [43]. The increased plant defense responses during the biotrophic phase will trigger ROS overproduction, causing cellular damage in the fungus and a change toward the necrotrophic lifestyle [43]. A phytopathogen's biotrophic phase can often be prolonged due to evolution under selection pressure in order to avoid host defense responses and weaken the ETI of the host [44]. Effectors are important to suppress PTI and $\mathrm{HR}$, assisting disease development by inducing the abscisic acid (ABA) pathway and producing metabolites to suppress jasmonic acid (JA)- and salicylic acid (SA)-induced defense responses by the plant host $[44,52,53]$. The failure of the plant host to detect the effectors will reduce the production of plant resistance proteins (RPs), whereas the failure to trigger ETI leads to the susceptibility of the pathogen. During the necrotrophic phase, the fungus will secrete various phytotoxic compounds and CWDEs to cause nutrient leakage $[43,52]$. As the infection becomes more severe, hyphae outside the root will form tough and melanized mycelia by encapsulating the thin-walled hyphae with layers of thick-walled cells around the roots, resulting in massive hyphae aggregations and the formation of basidiocarps [36]. The presence of basidiocarps on an infected palm signifies that the plant is in the severe infection stage, and the progression of decay has occurred inside the plant. Over time, the plant will die, and the necrotrophic phytopathogen causing plant death will continue to live saprotrophically.

The microscopic examination of infected palms at the cellular level revealed the establishment of biotrophic nutrition by G. boninense during colonization. The fungus degrades 
the lignin to weaken the rigid plant cell-wall structure prior to starch consumption [36]. Generally, three key events occur during host colonization by hemibiotrophs, namely, (i) penetration, (ii) nutrient absorption at the expense of the host, and (iii) host death [36]. Currently, little is known on the proteins or enzymes involved during host penetration, whereas the second and third components are well characterized in G. boninense pathogenesis. A recent study has shown that a reduction of G. boninense colonization occurred along with a significant up-regulation of the pathogenesis-related protein 1-like (PR-1) gene, which is produced as part of the oil palm's defense mechanism [43]. They further proposed that the high expression of PR-1 resulted in the sequestration of ergosterol, a part of the primary metabolite and cell-wall component in G. boninense. PR-1 protein has been reported to have fungicidal properties and is produced by the host plant to combat the further invasion of the host by fungal pathogens [43].

Recently, it was revealed that $G$. boninense colonizes the host by forming needle-like microhyphae that facilitate the penetration of oil palm roots [37]. The thin-walled microhyphae usually have an extracellular matrix that undergoes a highly localized degradation of its cellulose component, resulting in a matrix that extends into minute cracks of the cell wall (Figure 3). This feature has also been observed in other fungal pathogens such as Fusarium oxysporum [54] and Heterobasidion parviporum [55]. In contrast, the microhyphae produced by Neurospora crassa, Ophiostoma ulmi and Phellinus noxius are activated during growth in the presence of inhibitors [56]. In response, the plant reacts by enhancing ROS production through an oxidative burst [57].

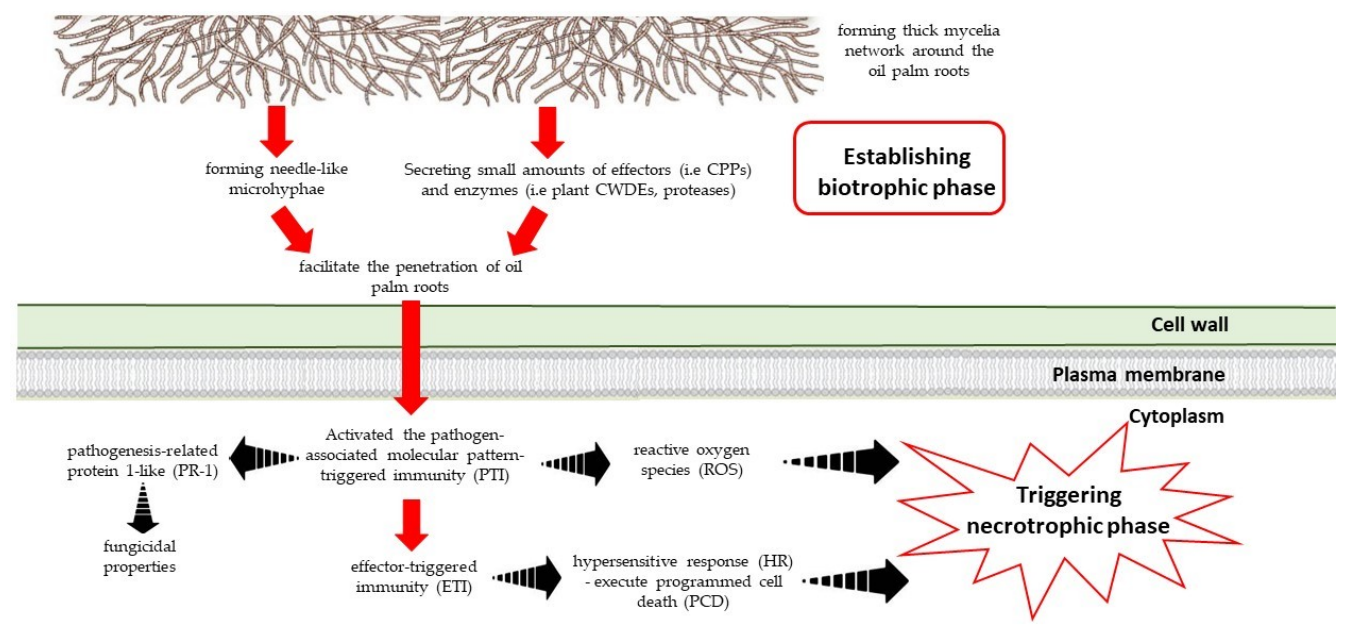

Figure 3. The interaction between fungal pathogen (G. boninense) and the plant (oil palm root).

\section{G. boninense Multi-Omics Data}

With the advancement and improvement of sequencing technologies, genome and transcriptome sequencing has become the approached method in understanding microbial interactions with the environment [58,59], animal hosts [60] and plant hosts [61,62]. Currently, the genomes of five pathogenic strains of G. boninense have been sequenced: two strains isolated from Indonesia, i.e., the strains NJ3 and G3 [63,64]; and three strains isolated from Malaysia, i.e., PER71, BRIUMSc [65] and FGV-M [66]. All genome datasets are freely available from the NCBI database (Table 1).

The difference in the genome size between all the sequenced G. boninense strains suggests that a high genome diversity exists between these strains, and perhaps, portions of the genome have suffered duplications or deletions during the evolution of the various strains. In addition, the complete mitochondrial genome of this fungus is $86,549 \mathrm{bp}$. The total number of genes encoding for proteins is 51 , with 15 conserved proteins, 4 hypothetical proteins, 5 homing endonucleases and 27 tRNAs, as well as small and large rRNA subunits [67]. Furthermore, a pan-genome analysis of eight draft genomes of Ganoderma sp. showed that of 35,121 orthologous genes (OGs), only 4898 genes are shared in all species [68]. The re- 
maining 30,223 genes were classified as accessory genes in the genome, among which 1905 are species-specific genes. Interestingly, comparative genomic analyses between the nonpathogenic G. lucidum and the pathogenic G. boninense led to the discovery of 607 genes found only in the genome of G. boninense, thus suggesting their role in G. boninense's pathogenicity toward its host [68]. Most phytopathogenic fungi have well-established arsenals of carbohydrate-active enzymes (CAZymes), including CWDEs secreted during infection. A recent study has shown that the G. boninense genome has 755 CAZyme- encoding genes, of which 465 encode for CWDEs, including carbohydrate esterases (CE), glycoside hydrolases (GH) and polysaccharide lyases (PL) [47].

Table 1. Current whole genomic and mitochondria data of G. boninense available in the public database.

\begin{tabular}{|c|c|c|c|c|c|}
\hline Strain & Source of Isolate & Sample Type & Genome Size & Accession & Reference \\
\hline PER71 & $\begin{array}{l}\text { Peninsular } \\
\text { Malaysia, } \\
\text { Malaysia }\end{array}$ & Genomic DNA & - & PRJNA182005 & $\begin{array}{l}\text { Broad } \\
\text { Institute }\end{array}$ \\
\hline NJ3 & $\begin{array}{l}\text { North Sumatra, } \\
\text { Indonesia }\end{array}$ & Genomic DNA & $65.03 \mathrm{Mb}$ & PRJNA287769 & {$[64]$} \\
\hline G3 & $\begin{array}{l}\text { North Sumatera, } \\
\text { Indonesia }\end{array}$ & Genomic DNA & $79.24 \mathrm{Mb}$ & PRJNA421251 & [63] \\
\hline FGV-M & $\begin{array}{c}\text { Peninsular } \\
\text { Malaysia, } \\
\text { Malaysia }\end{array}$ & Genomic DNA & $66.57 \mathrm{Mb}$ & PRJNA503786 & {$[66]$} \\
\hline BRIUMSc & Borneo, Malaysia & Genomic DNA & $52.28 \mathrm{Mb}$ & PRJNA553124 & [65] \\
\hline G3 & $\begin{array}{l}\text { North Sumatera, } \\
\text { Indonesia }\end{array}$ & $\begin{array}{l}\text { Mitochondrial } \\
\text { DNA }\end{array}$ & $86,549 \mathrm{bp}$ & PRJNA421251 & [67] \\
\hline
\end{tabular}

The genomic analysis of the publicly available genome databases of Ganoderma sp. strain 10,597 SS1, G. lucidum strain Xiangnong No.1, G. lucidum BCRC 37,177 and G. lucidum strain G.260125 has found that the products of the mat $A$ genes from all strains are highly dissimilar in sequence, and hence represent four different mating type specificities [23]. As for the $m a t B$ genes, around 8 to 9 different pheromone receptor genes and 10 pheromone precursors were found to be located within a $60-100 \mathrm{~kb}$ long sequence region in all 4 genome databases.

Three different RNAseq G. boninense libraries, namely the monokaryon, dikaryon and the mating junction of two compatible monokaryons, were generated and analyzed [69]. These datasets were deposited and are publicly available in the NCBI database with accession number PRJNA269646. Several mating factors were up-regulated in the mating junction library, including the pheromone receptor, STE3 [70], which is involved in the mating signaling pathway of other fungi [71], thus confirming their function in the formation of the dikaryon in G. boninense.

To further identify the pathogenicity factors produced by this fungus during infection, RNAseq analyses of the fungus were carried out on the infected plant host. The RNAseq data is available in the NCBI database with the accession number PRJNA514399 and is the first reported data to uncover the molecular mechanisms and pathways during G. boninense infection toward the oil palm in planta. However, external environmental factors such as temperature, osmotic stress and moisture have affected the expression levels of several pathogenicity genes [72]. Several genes including CAZymes, which belongs to six families of auxiliary activities (AA) enzymes—such as five multicopper oxidases (AA1_1), four glucose-methanol-choline (GMC) oxidoreductases (AA3) and a copy of peroxidase (AA2), copper radical oxidase (AA5), and benzoquinone reductase (AA6) -were up-regulated in the fungal-plant interaction [49]. Besides, a copper-dependent lytic polysaccharide monooxygenase (LPMO) which belongs to the AA9 (formerly GH61) family was also up-regulated during its interaction with the plant host [49] (Table 2). The oil palm tree expressed several genes as its defense, such as the pathogenesis-related protein 1-like 
(EgPR-1), expansin-B18-like (EgEXPB18) and chitinases ( $E g C h t)$, which were significantly up-regulated during the early stage of infection ( 3 and 7 days post-inoculation). Besides, some genes were down-regulated during the infection by G. boninense, such as GDSL esterase/lipases 5 (EgGLIP5) and monogalactosyldiacylglycerol synthase 1 (EgMGD1) [43], which has been simplified in Table 2 .

Phytopathogenic fungi, including G. boninense, secrete several non-catalytic proteins, including cerato-platanin proteins (CPPs), which play essential roles in the interactions between fungi and hosts. Many CPPs are available in plant pathogenic fungi, and these proteins serve as virulence factors in the interactions of fungi with plants [73]. Our preliminary analyses have identified 22 CPPs in the genome of G. boninense G3 (unpublished data). Generally, CPP encoding genes' expression was higher during the early phase of infection [68]; however, a previous study has shown that G. boninense CPP is down-regulated during the infection [49]. We hypothesize that the infection was at the late phase because the sample was collected 30 days after inoculation. Thus, the fungus did not require CPPs to be expressed, as the host immune system had been activated.

RNAseq data sequences of infected oil palm tissues from three different conditions, including the healthy section of infected oil palm (IPHT), the near-rot section of infected oil palm (IPIT) and the cross-section of a healthy tissue section of healthy oil palm tree (HPHT), have been generated [74]. These data will undoubtedly lead to a better understanding of the genes responsible for, and implicated in, G. boninense infection toward its host. The raw RNAseq reads are available in the BioProject (NCBI) with the accession number PRJNA530030.

Several genes encoding CWDEs, especially transcripts involved in the lignin degradation process, including the laccase genes, were up-regulated in a carbon-rich culture incorporating oil palm sawdust [48]. Laccase has diverse biological functions, and several studies have shown that fungal laccases also play a role in pathogenicity. G. boninense's genome possesses 33 laccase encoding genes. However, the expression levels of these laccase genes were unique depending on the aggressiveness of the $G$. boninense strain; high virulence (I13), moderate virulence (NJ3) and low virulence (G13) with 11, 7 and 5 laccase genes, respectively, were up-regulated [48]. It was postulated that the differentially expressed laccase transcripts between isolates were related to the capability of the strain to degrade the stem. In addition, another study has shown that two cyclophilin genes (GbCYP203 and GbCYP205) were up-regulated during in vitro infection toward the oil palm and were postulated to be involved in G. boninense pathogenicity [75]. Furthermore, another gene postulated to play a role in the pathogenicity of $G$. boninense, known as necrosis and ethylene-inducing 2 protein (GbNEP), was studied. The gene encoding GbNEP was cloned and expressed recombinantly in a bacterial system. The infection assay of the recombinant protein (in vitro) revealed that the rGbNEP could induce necrosis in tobacco and tomato. However, the rGbNEP was unable to induce the same symptoms in oil palm leaves and root tissues [76].

Studies on the global gene expression analysis of the host response after the inoculation with G. boninense have shown that the plant host expresses several genes that are required in the biosynthesis of phytohormones such as ethylene, methyl jasmonate (MeJA) and methyl salicylate (MeSA). Furthermore, several antioxidants, such as L-ascorbate and myoinositol, were also highly expressed, whereas many genes required for photosynthesis were downregulated during infection by this fungus [53]. The oil palm also produces PR proteins such as protease inhibitors, chitinases and secondary metabolites that possess fungicidal properties against $G$. boninense as its defense response to the fungal pathogen [43,52]. All data generated from these different studies could be used to determine the genes responsible for infecting the oil palm tree (Table 3). 
Table 2. List of up-regulated and down-regulated genes between G. boninense and the plant host seedlings, E. guineensis.

\begin{tabular}{|c|c|c|}
\hline Gene(s) & Up-Regulated Genes & Down-Regulated Genes \\
\hline \multicolumn{3}{|c|}{ Fungus (G. boninense) [49] } \\
\hline \multicolumn{3}{|c|}{ Plant Cell Wall Degrading Enzymes (CWDEs) } \\
\hline multicopper oxidases (AA1_1) & $/(5)$ & - \\
\hline glucose-methanol-choline (GMC) oxidoreductases (AA3) & $/(4)$ & - \\
\hline peroxidase (AA2) & $/(1)$ & - \\
\hline copper radical oxidase (AA5) & $/(1)$ & - \\
\hline benzoquinone reductase (AA6) & $/(1)$ & - \\
\hline $\begin{array}{l}\text { copper dependent lytic polysaccharide monooxygenase (LPMO) } \\
\text { (AA9) }\end{array}$ & $/(1)$ & - \\
\hline xyloglucan hydrolases $(\mathrm{GH} 16)$ & $/(2)$ & - \\
\hline carboxylesterase enzymes & $/(2)$ & - \\
\hline$\alpha$-glucosidase (GH31) & $/(1)$ & - \\
\hline$\beta$-galactosidases (GH35) & $/(2)$ & - \\
\hline$\alpha$-glucuronidases (GH15) & $/(2)$ & - \\
\hline$\beta$-glucuronidases (GH79) & $/(2)$ & - \\
\hline pectate lyases 3 (PL3) & $/(2)$ & - \\
\hline pectate lyases 8 (PL8) & $/(1)$ & - \\
\hline \multicolumn{3}{|c|}{ Fungal Cell Wall Remodeling and/or Degrading Enzymes } \\
\hline chitin synthase (CHS) & $/(1)$ & - \\
\hline chitinase & $/(1)$ & $/(5)$ \\
\hline endochitinase & $/(1)$ & - \\
\hline Beta-glucanase & - & $/(2)$ \\
\hline \multicolumn{3}{|c|}{ Small Secreted Proteins } \\
\hline hydrophobins & - & $/(4)$ \\
\hline cerato platanins & - & $/(3)$ \\
\hline \multicolumn{3}{|c|}{ Stress Response Proteins } \\
\hline thaumatin-like proteins & - & $/(5)$ \\
\hline \multicolumn{3}{|l|}{ Protease } \\
\hline metalloproteases & $/(5)$ & - \\
\hline
\end{tabular}

Oil palm (E. guineensis) root tissues [43]

Pathogenesis-Related (PR) Proteins

pathogenesis-related protein 1-like ( $E g P R-1)$

peroxidases $(E g P E R)$

germin-like proteins $(E g G L P)$

chitinases $(\mathrm{EgCht})$

Secondary Cell Wall Biosynthetic Genes

cellulose synthase A catalytic subunits (EgCESA)

cellulose synthase-like proteins $(E g C S L)$

expansin-B18-like (EgEXPB18)

\section{Lipid Metabolism}

GDSL esterase/lipases 5 (EgGLIP5)

monogalactosyldiacylglycerol synthase 1 (EgMGD1)

$\begin{array}{ll}/ & - \\ / & - \\ / & - \\ / & -\end{array}$

/


Table 3. Current G. boninense-related transcriptomic data are available in the public database.

\begin{tabular}{cllc}
\hline Transcriptome Data & \multicolumn{1}{c}{ Sample } & Accession & Reference \\
\hline G. boninense & $\begin{array}{l}\text { Monokaryon } \\
\text { Dikaryon } \\
\text { Mating Junction } \\
\text { axenic culture } \\
\text { pathogen-oil palm interaction } \\
\text { infected with G. boninense } \\
\text { infected with G. boninense }+\end{array}$ & PRJNA269646 & PRJNA5] \\
Oil palm root & PRJEB7252 & [72] \\
Oil palm & $\begin{array}{l}\text { infected by G. boninense } \\
\text { infected with G. boninense } \\
\text { early interaction with G. boninense }\end{array}$ & PRJNA530030 & {$[77]$} \\
Oil palm leaf & PRJEB17971 & {$[53]$} \\
\hline
\end{tabular}

\section{Detection and Control Strategies}

To date, no disease management method has been effective [10] in preventing the continuing spread of Ganoderma disease. The primary mode of infection occurs in the soil, thus making detection difficult [78]. Current detection methods rely on observing visible symptoms exhibited by infected trees, such as a yellowing and orange discoloration of the leaves, withering, crown flattening and unopened spear leaves [79]. However, this detection method sometimes results in misdiagnosis because these symptoms could also be caused by other factors, such as malnutrition and drought. The appearance of G. boninense fruiting bodies on the infected trees indicates that the disease is already at the late stage of infection [7]. In advanced cases, the oil palm stem might rupture [42], thus restricting the absorption of water and nutrients from the roots to the leaves, leading to chlorosis [13].

A typical early detection method for BSR involves the drilling of suspected infected plant material from the palm tree. The plant sample is then cultivated on selective media to detect the presence of Ganoderma [80]. This method is time-consuming and inaccurate, and the disease is already well-established by the time results are generated. Molecular detection methods began to be developed after 2000 due to the advancement of techniques during that time. A PCR-based detection was developed, involving a combination of primers used to amplify specific markers for Ganoderma detection [81]. A detection method utilizing an immuno-based assay by an enzyme-linked immunosorbent assay (ELISA) using monoclonal antibodies was developed [82]. The immunosorbent assay has the advantage of being more straightforward and faster compared to PCR; however, the results were varied and inconsistent [83]. In addition, these assays produced false positives and cross-reactivity with other fungi commonly found in oil palm plantations [82,84].

Currently, research has been focused on developing new detection methods that are fast and highly specific. Loop-mediated isothermal amplification (LAMP)-based detection was developed because it is highly sensitive as compared to PCR-based techniques, where it only requires a $0.002 \mathrm{ng} / \mu \mathrm{L}$ DNA template compared to the $0.02 \mathrm{ng} / \mu \mathrm{L}$ needed for PCR-based detection methods [85]. In addition, the LAMP primer pair designed to amplify bug1A showed the potential to be used in detection because it can specifically identify and differentiate pathogenic Ganoderma species (such as G. boninense, G. zonatum and G. miniatocinctum) from other non-pathogenic Ganoderma [85]. Moreover, this LAMP-based detection technique is superior in detecting pathogenic Ganoderma species as compared to ELISA, which results in cross-reactivity and false-positive outcomes due to the unsuccessful blocking between the antigen and the G. boninense polyclonal antibody. Another advantage of using LAMP is its simpler sample preparation, minimizing cross-contamination and generating results within 30 and $60 \mathrm{~min}$ [86]. Furthermore, the researcher can alter the reaction mixture according to their preference, and the experiments can be visualized on-site by a portable machine.

Furthermore, several groups have focused on developing a new detection method using electrochemical sensors with different types of particles, including gold nanoparticles 
(AuNPs) and carbon nanotubes (CNTs) $[87,88]$. Recently, a combination of polymer pen lithography (PPL) and DNA-gold nanoparticle (DNA-AuNP) conjugates were developed for $G$. boninense [89]. This technique provides better precision in detecting G. boninense in plant samples, including the unamplified genomic DNA of this fungus. However, these electrochemical sensing methods are costly and time-consuming and can only detect BSR at the later stage of infection. Therefore, it is vital to develop faster and cheaper methods for detecting this fungus, especially at the early stages of infection.

Various methods have been used to control BSR, including soil mounding and surgical removal of dead plant tissue, together with the basidiocarps and chemical treatments by injecting fungicides into the tree [13,79]. Some plantations, however, still practice the burning of infected materials, creating environmental issues in the region.

Several fungicidal chemicals have been tested for Ganoderma, and one of the most widely tested chemicals in the field is hexaconazole $[40,90]$. Hexaconazole is able to reduce the risk of Ganoderma infection in healthy mature palm trees [34]; however, field tests have shown that the fungicide residues are moderately present in leaf samples up to 70 days after the treatment [91]. Another chemical that shows potential in Ganoderma treatment is a microgranular fumigant known as dazomet, which emits a toxic gas known as methyl isothiocyanate (MITC) when it interacts with water [92]. Dazomet treatment (1000 g) can prevent the growth of a Ganoderma inoculum up to $90 \%$ in infected stumps [93]. A recent study identified pyraclostrobin, which could be used as a fungicidal agent against G. boninense. Pyraclostrobin has shown dual functions: suppressing G. boninense while concomitantly improving plant growth. Pyraclostrobin also induces the host-defenserelated gene, $\beta$-1,3-glucanase [94]. However, further investigation is still required to determine the effect of the continuous usage of this fungicide on the biodiversity of the soil microbiome, as well as its effect on the environment.

With numerous unsuccessful attempts to reduce the disease and the concerning effect of fungicides on the environment, the current focus of research has shifted toward identifying potential biological control agents against the fungus. One of these focuses is the identification of microbial antagonists to the phytopathogen. Although several potential microbial biological control agents have been identified, including bacteria [12,95], actinomycetes [95,96], endophytes [97], fungi [98] and seaweed [99], these biological control methods do not act universally toward G. boninense (Table 4). An efficient microbial biological control agent with a high percentage inhibition of radial growth (PIRG) values toward one strain of G. boninense did not exhibit similar high PIRG values toward a different dikaryotic strain of the same fungus. This is believed to be compounded by the tetrapolar G. boninense mating system, which renders it highly capable of diversifying its genetic makeup, leading to a variation in genome composition [100]. An advantage of bio-control agents is their ability to evolve and adapt along with the phytopathogen, often showing primacy over them. At the same time, it must be noted that their ability to adapt determines not only the success of the control of the target pests, but also the possibility (and extent) of non-target effects. Thus, follow-up studies or long-term monitoring needs to be considered to properly assess the effect of bio-control agents in field conditions outside of controlled laboratory settings. Furthermore, questions have also been raised regarding the execution of this method, especially regarding the cost and reliability of biological agents in alternative disease control strategies [10,100,101].

Biological control agents often secrete specific substances, otherwise known as secondary metabolites, responsible for their fungistatic and/or fungicidal effects on fungal pathogens [103]. Currently, a few compounds isolated from different microbial species were able to inhibit the growth of $G$. boninense in vitro. For example, Trichoderma virens produce specific compounds such as phenylethyl alcohol (PEA), 3,4-dimethylpent-2-en1-ol and dodecanoic acid [98,104], whereas a mixture of several Bacillus spp. and Trichoderma spp. produced pyrene-1,6-dione, $\mathrm{N}$-acetyl-leu-leu-tyr-amide and 12-deoxyaklanonic acid [105]. A powdered mixture containing bio-control agents Streptomyces sp., such as Streptomyces hygroscopicus, and known antifungal producer Streptomyces noursei showed a 
strong inhibition $(P I R G=100)$ against $G$. boninense in vitro [102]. Furthermore, this formulation also reduced the disease incidence in oil palm seedlings to up to $73 \%$ after 6 months of G. boninense inoculation [102]. Streptomyces sp. was known to produce several antifungal compounds which might inhibit the growth of $G$. boninense, such as ribostamycin, salinomycin and benzylmalic acid [106]. Besides that, another Streptomyces sp. known as Streptomyces palmae CMU-AB204 ${ }^{\mathrm{T}}$ also show the potential to be used as a bio-control agent against $G$. boninense. The treatment of this microbe against $G$. boninense showed a reduced percentage of disease severity (DS) of $81.6 \%$ and reduced the severity of foliar symptoms (SFS) to $3.7 \%$ when the free-spores were applied to the seedlings. Moreover, DS and SFS were also reduced to $75.8 \%$ and $4.5 \%$ when the spores were encapsulated with alginate beads [107]. This actinomycete produced several bioactive compounds, such as actinopyrone $\mathrm{A}$, anguinomycin $\mathrm{A}$ and leptomycin $\mathrm{A}$, which inhibited the growth of G. boninense $[107,108]$. These compounds have the potential to be commercialized; however, further studies need to be carried out before they are used in oil palm plantations.

Table 4. In vitro test of bio-control agents against G. boninense.

\begin{tabular}{|c|c|c|c|c|c|}
\hline \multirow[b]{2}{*}{ Bio-Control Agent } & \multicolumn{2}{|c|}{ Dual Culture } & \multicolumn{2}{|c|}{ Other Test } & \multirow[b]{2}{*}{ Reference } \\
\hline & $\begin{array}{c}\text { PIRG Value } \\
(\%)\end{array}$ & Test & $\begin{array}{c}\text { PIRG Value } \\
(\%)\end{array}$ & Test & \\
\hline Pseudomonas aeruginosa & 70.0 & Dual culture & 80.0 & Culture filtrate & [12] \\
\hline Burkholderia cepacia & 55.5 & Dual culture & 65.0 & Culture filtrate & [12] \\
\hline Streptomyces hygroscopicus & $50.0-80.0$ & Dual culture & 100 & Powder formulation & {$[96,102]$} \\
\hline Streptomyces ahygroscopicus & $50.0-80.0$ & Dual culture & 100 & Powder formulation & {$[96,102]$} \\
\hline Aspergillus calidoustous BTF07 & 49.5 & Dual culture & - & - & [97] \\
\hline Trichoderma asperellum T2 & 47.5 & Dual culture & - & - & [97] \\
\hline Trichoderma virens $159 \mathrm{C}$ & - & - & 44.3 & Crude extract & [98] \\
\hline Sargassum oligocystum & 38.64 & Dual culture & 42.5 & Hexane extract & [99] \\
\hline
\end{tabular}

Recently, a new fertilizer known as GanoCare ${ }^{\circledR}$ was formulated from a combination of powdered empty fruit bunches (EFB) with a "beneficial element", including a higher content of calcium (Ca), silicon (Si), zinc ( $\mathrm{Zn}$ ) and boron (B) [109]. While the application of this fertilizer significantly reduces the disease incidence by up to $70 \%$, more in-depth studies are needed, specifically to uncover their effect on the biochemical responses of oil palms and the effect on oil production. Several studies suggested that these elements suppress several plant diseases and enhance the resistance to the BSR disease [110]. Besides, we believe that commercial GanoCare ${ }^{\circledR}$ also comprised a consortium of microorganisms that are able to suppress the growth of $G$. boninense. GanoCare ${ }^{\circledR}$ shows promise by improving oil palm growth and host resistance against Ganoderma infection [109]. Further molecular analysis is still needed, however, to uncover how GanoCare ${ }^{\circledR}$ boosts the defense-related mechanisms of the plant host against the fungus.

\section{Future Directions for R\&D}

Current studies have shown promising results toward determining the pathogenicity factors of this fungus using available molecular biology techniques. Next-generation sequencing could be the best option in elucidating the determinants of pathogenicity in this fungus. Although transcriptomic datasets between this fungus and plant hosts are publicly available, the implications gleaned from these datasets are not conclusive due to environmental factors. Thus, the most promising way forward in determining the pathogenicity factors is by infecting the oil palm tissue culture with G. boninense in a controlled environment to minimize external environmental factors. Recently, BSR incidents were predicted to increase due to climate change in 2100, especially in Malaysia and Sumatra $[5,14]$. The prediction is based on the fungus's higher virulence, which could reduce the oil palm resistance to the disease due to the unsuitable climate for oil palm. This 
situation will increase the risk of the unsustainability of oil palm production for the world's two largest oil palm producers.

Moreover, the draft genomes available are as yet incomplete assemblies, which poses a significant problem for accurate gene characterization. The difference in the number of genes generated is perhaps due to the incomplete or fragmented nature of the next generation sequencing (NGS) datasets. Thus, an improved genome assembly, perhaps by utilizing a hybrid genome assembly approach, is needed to accelerate molecular studies of this phytopathogen.

One of the fundamental issues in solving the enigma of this fungus is how the monokaryon selects a compatible partner to form the infective dikaryon. Transcriptome data proved useful in identifying the candidate factors, such as the Ste3 gene, that are essential in activating the mating signaling pathway [70]. An Agrobacterium-mediated transformation has been successfully developed [37]. This technique could be utilized in functional genomics studies; however, the technique is not compatible with the G. boninense mycelia. Thus, promising genome editing based techniques such as the CRISPR/Cas9 system, conventional homologous recombination or transformation methods may serve as more promising tools to advance knowledge on G. boninense. Developing such methods will be vital for functional genomics studies of $G$. boninense, especially in identifying the virulence factors during the infection [34].

The most studied Ganoderma species is currently G. lucidum, due to its medicinal properties. Some studies have identified that $G$. boninense also exhibits antibacterial activity against few nosocomial-infection-related bacterial pathogens, including Escherichia coli, Klebsiella pneumonia, Pseudomonas aeruginosa, Salmonella enterica, Staphylococcus aureus and Streptococcus pyogenes [111]. A further study has identified two compounds, ergosterol and ganoboninketal, which possess a potent antibacterial activity against $S$. aureus and S. pyogenes [112]. However, clinical studies mainly on the effect of the antibacterial compounds still need to be carried out to determine the suitability of these compounds produced by G. boninense as drug candidates.

A recent study has identified four Ganoderma resistance loci in oil palm, where two of them were involved in regulating the incidence of the first Ganoderma symptoms, while the other two were involved in the death of palm trees [113]. Thus, this information is vital in developing a breeding program to produce new oil palm (Elaeis guineensis Jacq.) varieties that are more resistant to the fungal pathogen.

\section{Conclusions}

Studies have shown the mechanism of infections governed by G. boninense which stealthily penetrate and colonize the host cell. Moreover, with the availability of NGS technologies, few genes related to the pathogenicity of this fungus have been identified. However, there are no disease management strategies that can efficiently stop the Ganoderma disease's continuing spread. Future research should focus on the variability of the genetic content between the fungal strains at the molecular level, as this factor has contributed a variable tolerance to the current disease treatments. Besides, developing a suitable method for functional genomic analysis would complement and gear up the development of new approaches to cure the infected palms or control the spread of this fungus, aiming to maintain sustainable oil palm production.

Author Contributions: Conceptualization, I.B. and A.F.F.A.W.; writing-original draft preparation, I.B., A.F.F.A.W., M.A.A.S. and N.X.Y.; writing-review and editing, I.B., A.F.F.A.W., M.A.Z., F.D.A.B. and A.M.A.M.; funding acquisition, I.B. and A.M.A.M. All authors have read and agreed to the published version of the manuscript.

Funding: This research was funded by Universiti Kebangsaan Malaysia, grant number DIP-2019-022 and GGPM-2017-071.

Institutional Review Board Statement: Not applicable. 
Informed Consent Statement: Not applicable.

Data Availab ility Statement: Not applicable.

Acknowledgments: This work was supported by Universiti Kebangsaan Malaysia (grant number: DIP-2019-022 and GGPM-2017-071). We also like to thank Jonathan Ling for his critical review of this manuscript and Walter Aaron Wong Chun Yin, Anis Farhan Fatimi Ab Wahab, Madihah Ahmad Zairun and Izwan Bharudin for providing the pictures used in this manuscript.

Conflicts of Interest: The authors declare no conflict of interest. The funders had no role in the design of the study; in the collection, analyses, or interpretation of data; in the writing of the manuscript, or in the decision to publish the results.

\section{References}

1. Kushairi, A.; Ong-Abdullah, M.; Nambiappan, B.; Hishamuddin, E.; Izuddin, Z.; Ghazali, R.; Subramaniam, V.; Sundram, S.; Ghulam Kadir, A.P. Oil palm economic performance in Malaysia and R\&D progress in 2018. J. Oil Palm Res. 2019, 31, 165-194. [CrossRef]

2. Bedford, G. Advances in the control of rhinoceros beetle, Oryctes rhinoceros in oil palm. J. Oil Palm Res. 2014, 26, 183-194.

3. Abdul-Halim, W.N.M.; Muhaimin, A.M.D.; Syarifah-Zulaikha, S.A.; Nor Atikah, A.R.; Masri, M.M.M.; Yaakop, S. Evaluation of infestation in parasitoids on Metisa plana Walker (Lepidoptera: Psychidae) in three oil palm plantations in Peninsula Malaysia. Serangga 2017, 22, 135-149.

4. Harith-Fadzilah, N.; Haris-Hussain, M.; Abd Ghani, I.; Zakaria, A.; Amit, S.; Zainal, Z.; Azmi, W.A.; Jalinas, J.; Hassan, M. Physical and physiological monitoring on red palm weevil-infested oil palms. Insects 2020, 11, 407. [CrossRef]

5. Paterson, R.R.M. Ganoderma boninense disease deduced from simulation modelling with large data sets of future Malaysian oil palm climate. Phytoparasitica 2019, 47, 255-262. [CrossRef]

6. Midot, F.; Lau, S.Y.L.; Wong, W.C.; Tung, H.J.; Yap, M.L.; Lo, M.L.; Jee, M.S.; Dom, S.P.; Melling, L. Genetic diversity and demographic history of Ganoderma boninense in oil palm plantations of Sarawak, Malaysia inferred from ITS regions. Microorganisms 2019, 7, 464. [CrossRef]

7. Paterson, R.R.M. Ganoderma disease of oil palm-A white rot perspective necessary for integrated control. Crop Prot. 2007, 26, 1369-1376. [CrossRef]

8. Idris, A.S.; Mohd Shukri, I.; Izzuddin, M.A.; Norman, K.; Khairuman, H.; Ramle, M.; Iptizam, N.; Dayang, N.S. Survey on Status of Ganoderma Disease of Oil Palm Estates and Smallholders in Malaysia. In Proceedings of the MPOB International Palm Oil Congress and Exhibition (PIPOC) 2019, Kuala Lumpur, Malaysia, 19-21 November 2019; Volume 2, pp. 548-557.

9. Barcelos, E.; Rios, S.d.A.; Cunha, R.N.V.; Lopes, R.; Motoike, S.Y.; Babiychuk, E.; Skirycz, A.; Kushnir, S. Oil palm natural diversity and the potential for yield improvement. Front. Plant Sci. 2015, 6, 190. [CrossRef]

10. Siddiqui, Y.; Surendran, A.; Paterson, R.R.M.; Ali, A.; Ahmad, K. Current strategies and perspectives in detection and control of basal stem rot of oil palm. Saudi J. Biol. Sci. 2021, 28, 2840-2849. [CrossRef] [PubMed]

11. Chong, K.P.; Dayou, J.; Alexander, A. Pathogenic nature of Ganoderma boninense and basal stem rot disease. In Detection and Control of Ganoderma boninense in Oil Palm Crop; Chong, K.P., Dayou, J., Alexander, A., Eds.; Springer International Publishing: Cham, Switzerland, 2017; pp. 5-12.

12. Ramli, N.R.; Mohamed, M.S.; Abu Seman, I.; Ahmad Zairun, M.; Mohamad, N. The potential of endophytic bacteria as a biological control agent for Ganoderma disease in oil palm. Sains Malays. 2016, 45, 401-409.

13. Hushiarian, R.; Yusof, N.A.; Dutse, S.W. Detection and control of Ganoderma boninense: Strategies and perspectives. SpringerPlus 2013, 2, 555. [CrossRef]

14. Pilotti, C.A. Stem rots of oil palm caused by Ganoderma boninense: Pathogen biology and epidemiology. Mycopathologia 2005, 159, 129-137. [CrossRef] [PubMed]

15. Paterson, R.R. Ganoderma boninense disease of oil palm to significantly reduce production after 2050 in Sumatra if projected climate change occurs. Microorganisms 2019, 7, 24. [CrossRef] [PubMed]

16. Pilotti, C.A.; Gorea, E.A.; Bonneau, L. Basidiospores as sources of inoculum in the spread of Ganoderma boninense in oil palm plantations in Papua New Guinea. Plant Pathol. 2018, 67, 1841-1849. [CrossRef]

17. Wong, W.C.; Tung, H.J.; Fadhilah, M.N.; Midot, F.; Lau, S.Y.L.; Melling, L.; Astari, S.; Hadziabdic, Đ.; Trigiano, R.N.; Goh, K.J.; et al. Genetic diversity and gene flow amongst admixed populations of Ganoderma boninense, causal agent of basal stem rot in African oil palm (Elaeis guineensis Jacq.) in Sarawak (Malaysia), Peninsular Malaysia, and Sumatra (Indonesia). Mycologia 2021, 113, 902-917. [CrossRef]

18. Kok, S.M.; Goh, Y.K.; Jiat, T.; Goh, K.; Wei Chee, W.; Goh, Y.K. In vitro growth of Ganoderma boninense isolates on novel palm extract medium and virulence on oil palm (Elaeis guineensis) seedlings. Malays. J. Microbiol. 2013, 9, 33-42. [CrossRef]

19. Pilotti, C.A.; Sanderson, F.R.; Aitken, E.A.B. Sexuality and interactions of monokaryotic and dikaryotic mycelia of Ganoderma boninense. Mycol. Res. 2002, 106, 1315-1322. [CrossRef]

20. Kües, U.; Casselton, L.A. Homeodomains and regulation of sexual development in basidiomycetes. Trends Genet. 1992, 8, 154-155. [CrossRef] 
21. Pilotti, C.A.; Sanderson, F.R.; Aitken, E.A.B. Genetic structure of a population of Ganoderma boninense on oil palm. Plant Pathol. 2003, 52, 455-463. [CrossRef]

22. Casselton, L.A.; Kües, U. The origin of multiple mating types in the model mushrooms Coprinopsis cinerea and Schizophyllum commune. In Sex in Fungi: Molecular Determination and Evolutionary Implications; Heitman, J., Kronstad, J.W., Taylor, J.W., Casselton, L.A., Eds.; ASM Press: Washington, DC, USA, 2007; pp. 283-300. [CrossRef]

23. Kües, U.; Nelson, D.R.; Liu, C.; Yu, G.-J.; Zhang, J.; Li, J.; Wang, X.-C.; Sun, H. Genome analysis of medicinal Ganoderma spp. with plant-pathogenic and saprotrophic life-styles. Phytochemistry 2015, 114, 18-37. [CrossRef]

24. James, T.Y.; Lee, M.; van Diepen, L.T.A. A single mating-type locus composed of homeodomain genes promotes nuclear migration and heterokaryosis in the white-rot fungus Phanerochaete chrysosporium. Eukaryot. Cell 2011, 10, 249-261. [CrossRef]

25. Casselton, L.A.; Olesnicky, N.S. Molecular genetics of mating recognition in basidiomycete fungi. Microbiol. Mol. Biol. Rev. 1998, 62, 55-70. [CrossRef]

26. Mohanta, T.K.; Mohanta, N.; Parida, P.; Panda, S.K.; Ponpandian, L.N.; Bae, H. Genome-wide identification of mitogen-activated protein kinase gene family across fungal lineage shows presence of novel and diverse activation loop motifs. PLoS ONE 2016, 11, e0149861. [CrossRef]

27. Asante-Owusu, R.N.; Banham, A.H.; Böhnert, H.U.; Mellor, E.J.C.; Casselton, L.A. Heterodimerization between two classes of homeodomain proteins in the mushroom Coprinus cinereus brings together potential DNA-binding and activation domains. Gene 1996, 172, 25-31. [CrossRef]

28. Morrow, C.A.; Fraser, J.A. Sexual reproduction and dimorphism in the pathogenic basidiomycetes. FEMS Yeast Res. 2009, 9, 161-177. [CrossRef] [PubMed]

29. Metin, B.; Findley, K.; Heitman, J. The mating type locus (MAT) and sexual reproduction of Cryptococcus heveanensis: Insights into the evolution of sex and sex-determining chromosomal regions in fungi. PLoS Genet. 2010, 6, e1000961. [CrossRef]

30. Sun, S.; Heitman, J. Is sex necessary? BMC Biol. 2011, 9, 56. [CrossRef] [PubMed]

31. Olivera, P.D.; Sikharulidze, Z.; Dumbadze, R.; Szabo, L.J.; Newcomb, M.; Natsarishvili, K.; Rouse, M.N.; Luster, D.G.; Jin, Y. Presence of a sexual population of Puccinia graminis f. sp. tritici in Georgia provides a hotspot for genotypic and phenotypic diversity. Phytopathology 2019, 109, 2152-2160. [CrossRef]

32. Kahmann, R.; Romeis, T.; Bölker, M.; Kämper, J. Control of mating and development in Ustilago maydis. Curr. Opin. Genet. Dev. 1995, 5, 559-564. [CrossRef]

33. Turner, P.D. The incidence of Ganoderma disease of oil palms in Malaya and its relation to previous crop. Ann. Appl. Biol. 1965, 55, 417-423. [CrossRef]

34. Govender, N.; Wong, M.-Y.; Paterson, R. Opportunities for new-generation Ganoderma boninense biotechnology. In Grand Challenges in Fungal Biotechnology; Nevalainen, H., Ed.; Springer: Cham, Switzerland, 2020; pp. 477-500.

35. Miller, R.; Holderness, M.; Bridge, P.; Chung, G.; Zakaria, M. Genetic diversity of Ganoderma in oil palm plantings. Plant Pathol. 1999, 48, 595-603. [CrossRef]

36. Rees, R.W.; Flood, J.; Hasan, Y.; Potter, U.; Cooper, R.M. Basal stem rot of oil palm (Elaeis guineensis); mode of root infection and lower stem invasion by Ganoderma boninense. Plant Pathol. 2009, 58, 982-989. [CrossRef]

37. Govender, N.; Wong, M.-Y. Detection of oil palm root penetration by Agrobacterium-mediated transformed Ganoderma boninense, expressing green fluorescent protein. Phytopathology 2017, 107, 483-490. [CrossRef] [PubMed]

38. Alexander, A.; Sipaut, C.S.; Dayou, J.; Chong, K.P. Oil palm roots colonisation by Ganoderma boninense: An insight study using scanning electron microscopy. J. Oil Palm Res. 2017, 29, 262-266. [CrossRef]

39. Darus, A.; Seman, I.A.; Hassan, A.H. Histopathological studies on colonization of oil palm root by Ganoderma boninense. Elaeis 1991, 3, 289-293.

40. Idris, A.S.; Arifurrahman, R.; Kushairi, A. Hexaconale as a preventive treatment for managing Ganoderma in oil palm. MPOB Inf. Ser. 2010, 75, 533-534.

41. Chan, J.J.; Latiffah, Z.; Liew, K.W.; Idris, A.S. Pathogenicity of monokaryotic and dikaryotic mycelia of Ganoderma boninense on oil palm seedlings and germinated seeds in Malaysia. Australas. Plant Pathol. 2011, 40, 222-227. [CrossRef]

42. Rees, R.W.; Flood, J.; Hasan, Y.; Wills, M.A.; Cooper, R.M. Ganoderma boninense basidiospores in oil palm plantations: Evaluation of their possible role in stem rots of Elaeis guineensis. Plant Pathol. 2012, 61, 567-578. [CrossRef]

43. Bahari, M.N.A.; Sakeh, N.M.; Abdullah, S.N.A.; Ramli, R.R.; Kadkhodaei, S. Transciptome profiling at early infection of Elaeis guineensis by Ganoderma boninense provides novel insights on fungal transition from biotrophic to necrotrophic phase. BMC Plant Biol. 2018, 18, 377. [CrossRef]

44. Lorang, J. Necrotrophic exploitation and subversion of plant defense: A lifestyle or just a phase, and implications in breeding resistance. Phytopathology 2018, 109, 332-346. [CrossRef]

45. Nadarajah, K.; Mat Razali, N.; Cheah, B.H.; Sahruna, N.S.; Ismail, I.; Tathode, M.; Bankar, K. Draft genome sequence of Rhizoctonia solani anastomosis group 1 subgroup 1A strain 1802/KB isolated from rice. Genome Announc. 2017, 5, e01188-17. [CrossRef]

46. Bhaskar Rao, T.; Chopperla, R.; Prathi, N.B.; Balakrishnan, M.; Prakasam, V.; Laha, G.S.; Balachandran, S.M.; Mangrauthia, S.K. A comprehensive gene expression profile of pectin degradation enzymes reveals the molecular events during cell wall degradation and pathogenesis of rice sheath blight pathogen Rhizoctonia solani AG1-IA. J. Fungi 2020, 6, 71. [CrossRef] [PubMed]

47. Ramzi, A.B.; Che Me, M.L.; Ruslan, U.S.; Baharum, S.N.; Nor Muhammad, N.A. Insight into plant cell wall degradation and pathogenesis of Ganoderma boninense via comparative genome analysis. PeerJ 2019, 7, e8065. [CrossRef] 
48. Tan, J.S.; Lee, Y.P.; Sulaiman, S.; Camus-Kulandaivelu, L.; Klopp, C.; Mercière, M.; Breton, F.; Durand-Gasselin, T.; Syed Alwee, S.S.R. The route to the development of basal stem rot resistance in oil palm (Elaeis guineensis) via the discovery of lignin degradation process in the pathogen Ganoderma boninense. In Proceedings of the International Symposia on Tropical and Temperate Horticulture-ISTTH2016, Cairns, Australia, 20-25 November 2016; Volume 1205, pp. 359-370. [CrossRef]

49. Dhillon, B.; Hamelin, R.C.; Rollins, J.A. Transcriptional profile of oil palm pathogen, Ganoderma boninense, reveals activation of lignin degradation machinery and possible evasion of host immune response. BMC Genom. 2021, 22, 326. [CrossRef]

50. Yu, X.; Feng, B.; He, P.; Shan, L. From chaos to harmony: Responses and signaling upon microbial pattern recognition. Annu. Rev. Phytopathol. 2017, 55, 109-137. [CrossRef]

51. Sahebi, M.; Hanafi, M.; Wong, M.-Y.; Abu Seman, I.; Azizi, P.; Faseleh jahromi, M.; Shokryazdan, P.; Abiri, R.; Mohidin, H. Towards immunity of oil palm against Ganoderma fungus infection. Acta Physiol. Plant. 2015, 37, 195. [CrossRef]

52. Ho, C.-L.; Tan, Y.-C.; Yeoh, K.-A.; Ghazali, A.-K.; Yee, W.-Y.; Hoh, C.-C. De novo transcriptome analyses of host-fungal interactions in oil palm (Elaeis guineensis Jacq.). BMC Genom. 2016, 17, 66. [CrossRef]

53. Ho, C.-L.; Tan, Y.-C.; Yeoh, K.-A.; Lee, W.-K.; Ghazali, A.-K.; Yee, W.-Y.; Hoh, C.-C. Leaf transcriptome of oil palm (Elaeis guineensis Jacq.) infected by Ganoderma boninense. Trees 2019, 33, 943-950. [CrossRef]

54. Ouellette, G.B.; Baayen, R.P.; Simard, M.; Rioux, D. Reactions of paratracheal cells of resistant and susceptible carnation (Dianthus caryophyllus) cultivars to vascular invasion by Fusarium oxysporum f. sp. dianthi. New Phytol. 2002, 156, 113-128. [CrossRef]

55. Mendgen, K.; Deising, H. Infection structures of fungal plant pathogens-A cytological and physiological evaluation. New Phytol. 1993, 124, 193-213. [CrossRef]

56. Mendgen, K.; Hahn, M.; Deising, H. Morphogenesis and mechanisms of penetration by plant-pathogenic fungi. Annu. Rev. Phytopathol. 1996, 34, 367-386. [CrossRef] [PubMed]

57. Torres, M.A.; Jones, J.D.G.; Dangl, J.L. Reactive oxygen species signaling in response to pathogens. Plant Physiol. 2006, 141, 373-378. [CrossRef] [PubMed]

58. Bharudin, I.; Abdul Rahim, S.N.; Abu Bakar, M.F.; Ibrahim, S.N.; Kamaruddin, S.; Latif, M.T.; Samsudin, M.W.; Abdul Murad, A.M.; Abu Bakar, F.D. De novo transcriptome resources of the lichens, Dirinaria sp. UKM-J1 and UKM-K1 collected from Jerantut and Klang, Malaysia. Data Brief 2018, 19, 2416-2419. [CrossRef] [PubMed]

59. Bharudin, I.; Abu Bakar, M.F.; Hashim, N.H.F.; Mat Isa, M.N.; Alias, H.; Firdaus-Raih, M.; Md Illias, R.; Najimudin, N.; Mahadi, N.M.; Abu Bakar, F.D.; et al. Unravelling the adaptation strategies employed by Glaciozyma antarctica PI12 on Antarctic sea ice. Mar. Environ. Res. 2018, 137, 169-176. [CrossRef]

60. Jazamuddin, F.M.; Aizat, W.M.; Goh, H.-H.; Low, C.-F.; Baharum, S.N. Transcriptome data of Epinephelus fuscoguttatus infected by Vibrio vulnificus. Data Brief 2017, 16, 466-469. [CrossRef]

61. Alias, N.N.; Basherudin, N.; Bakar, M.F.A.; Ahmad-Syazwan, S.; Muhammad, N.; Ahmad, M.F.; Abdullah, M.Z. De novo transcriptome sequencing and identification of upregulated genes involved in phenylpropanoid pathway of Acacia mangium in response to Ceratocystis infection. Malays. Appl. Biol. 2018, 47, 135-148.

62. Fradj, N.; de Montigny, N.; Mérindol, N.; Awwad, F.; Boumghar, Y.; Germain, H.; Desgagné-Penix, I. A first insight into North American plant pathogenic fungi Armillaria sinapina transcriptome. Biology 2020, 9, 153. [CrossRef] [PubMed]

63. Utomo, C.; Tanjung, Z.A.; Aditama, R.; Buana, R.F.N.; Pratomo, A.D.M.; Tryono, R.; Liwang, T. Draft genome sequence of the phytopathogenic fungus Ganoderma boninense, the causal agent of basal stem rot disease on oil palm. Genome Announc. 2018, 6, e00122-18. [CrossRef]

64. Mercière, M.; Laybats, A.; Carasco-Lacombe, C.; Tan, J.S.; Klopp, C.; Durand-Gasselin, T.; Alwee, S.S.R.S.; Camus-Kulandaivelu, L.; Breton, F. Identification and development of new polymorphic microsatellite markers using genome assembly for Ganoderma boninense, causal agent of oil palm basal stem rot disease. Mycol. Prog. 2015, 14, 103. [CrossRef]

65. Voo, C.L.Y.; Yeo, D.E.T.; Chong, K.-P.; Rodrigues, K.F. Draft genome sequence of a phytopathogenic Ganoderma sp. strain that causes basal stem rot disease on oil palm in Sabah, Malaysia. Microbiol. Resour. Announc. 2020, 9, e01240-19. [CrossRef]

66. Sulaiman, S.; Othman, N.Q.; Tan, J.S.; Lee, Y.P. Draft genome assembly dataset of the basidiomycete pathogenic fungus, Ganoderma boninense. Data Brief 2020, 29, 105167. [CrossRef] [PubMed]

67. Utomo, C.; Tanjung, Z.A.; Aditama, R.; Buana, R.F.N.; Pratomo, A.D.M.; Tryono, R.; Liwang, T. Complete mitochondrial genome sequence of the phytopathogenic basidiomycete Ganoderma boninense strain G3. Microbiol. Resour. Announc. 2019, 8, e00968-18. [CrossRef]

68. Sulaiman, S.; Yusoff, N.; Tan, J.S.; Lee, Y.P. Deciphering the pan-genome of Ganoderma sp. to depict potential genomic components that contribute to Ganoderma boninense pathogenicity. Malays. Appl. Biol. 2018, 47, 71-80.

69. Isaac, I.L.; Walter, A.W.C.Y.; Bakar, M.F.A.; Idris, A.S.; Bakar, F.D.A.; Bharudin, I.; Murad, A.M.A. Transcriptome datasets of oil palm pathogen Ganoderma boninense. Data Brief 2018, 17, 1108-1111. [CrossRef]

70. Ahmad Zairun, M.; Idris, A.S.; Kamaruddin, S.; Bharudin, I.; Abu Bakar, F.D.; Murad, A.M.A. Identification and characterization of a mating signalling gene from an oil palm pathogen, Ganoderma boninense. In AIP Conference Proceedings, Proceedings of the Postgraduate Colloquium of the Faculty-of-Science-and-Technology of the Universi-ti-Kebangsaan-Malaysia (UKM FST), Selangor, Malaysia, 4-6 April 2018; Hasbullah, S.A., Jumali, M.H.H., Ibrahim, K., Rasol, N.H.A., Latif, M.T., Ibrahim, N., Hanafiah, M.M., Eds.; AIP Publishing: Melville, NY, USA, 2019; Volume 2111, p. 040005.

71. Jones, S.K., Jr.; Bennett, R.J. Fungal mating pheromones: Choreographing the dating game. Fungal Genet. Biol. 2011, 48, 668-676. [CrossRef] [PubMed] 
72. Wong, M.Y.; Govender, N.T.; Ong, C.S. RNA-seq data of Ganoderma boninense at axenic culture condition and under in planta pathogen-oil palm (Elaeis guineensis Jacq.) interaction. BMC Res. Notes 2019, 12, 631. [CrossRef]

73. Frías, M.; Brito, N.; González, M.; González, C. The phytotoxic activity of the cerato-platanin BcSpl1 resides in a two-peptide motif on the protein surface. Mol. Plant Pathol. 2014, 15, 342-351. [CrossRef]

74. Othman, N.Q.; Sulaiman, S.; Lee, Y.P.; Tan, J.S. Transcriptomic data of mature oil palm basal trunk tissue infected with Ganoderma boninense. Data Brief 2019, 25, 104288. [CrossRef] [PubMed]

75. Lim, F.-H.; Fakhrana, I.N.; Rasid, O.A.; Idris, A.S.; Ho, C.-L.; Shaharuddin, N.A.; Parveez, G.K.A. Molecular cloning and expression analysis of Ganoderma boninense cyclophilins at different growth and infection stages. Physiol. Mol. Plant Pathol. 2017, 99, 31-40. [CrossRef]

76. Teh, C.-Y.; Pang, C.-L.; Tor, X.-Y.; Ho, P.-Y.; Lim, Y.-Y.; Namasivayam, P.; Ho, C.-L. Molecular cloning and functional analysis of a necrosis and ethylene inducing protein (NEP) from Ganoderma boninense. Physiol. Mol. Plant Pathol. 2019, 106, 42-48. [CrossRef]

77. Ho, C.-L.; Tan, Y.-C.; Yeoh, K.-A.; Lee, W.-K.; Ghazali, A.-K.; Yee, W.-Y.; Hoh, C.-C. Transcriptional response of oil palm (Elaeis guineensis Jacq.) inoculated simultaneously with both Ganoderma boninense and Trichoderma harzianum. Plant Gene 2018, 13, 56-63. [CrossRef]

78. Nawawi, A.; Ho, Y.W. Effect of temperature and $\mathrm{pH}$ on growth pattern of Ganoderma boninense from oil palm in Peninsular Malaysia. Pertanika 1990, 13, 303-307.

79. Chung, G.F. Management of Ganoderma diseases in oil palm plantations. Planter 2011, 87, 325-339.

80. Darus, A.; Chong, C.K.; Henson, I.E.; Sukaimi, J.; Wahid, M.B.; Mohd-Tayeb, D.; Paranjothy, K.; Rajanaidu, N. PORIM International Palm Oil Congress Update and Vision. Agriculture. Proceedings. In Proceedings of the PORIM International Palm Oil Congress Update and Vision, Kuala Lumpur, Malaysia, 20-25 September 1993.

81. Utomo, C.; Werner, S.; Niepold, F.; Deising, H.B. Identification of Ganoderma, the causal agent of basal stem rot disease in oil palm using a molecular method. Mycopathologia 2005, 159, 159-170. [CrossRef] [PubMed]

82. Ahmad Zairun, M.; Abu Seman, I.; Ar, R. Polyclonal antibodies of Ganoderma boninense isolated from Malaysian oil palm for detection of basal stem rot disease. Afr. J. Biotechnol. 2014, 13, 3455-3463. [CrossRef]

83. Utomo, C.; Niepold, F. Development of Diagnostic Methods for Detecting Ganoderma-infected Oil Palms. J. Phytopathol. 2000, 148, 507-514. [CrossRef]

84. Sundram, S.; Chris, D.; Sioban, O.; Idris, A. Preliminary studies on the development of monoclonal antibodies against mycelia of Ganoderma boninense, the causal pathogen of Basal Stem Rot of oil palm. Malays. J. Microbiol. 2006, 2(1), 30-34. [CrossRef]

85. Ahmad Zairun, M.; Maizatul-Suriza, M.; Idris, A.; Bakar, M.; Kamaruddin, S.; Bharudin, I.; Abu Bakar, F.; Murad, A. Comparison of DNA extraction and detection of Ganoderma, causal of basal stem rot disease in oil palm using loop-mediated isothermal amplification. Malays. Appl. Biol. 2018, 47, 119-127.

86. Fakruddin, M.; Mannan, K.S.B.; Chowdhury, A.; Mazumdar, R.M.; Hossain, M.N.; Islam, S.; Chowdhury, M.A. Nucleic acid amplification: Alternative methods of polymerase chain reaction. J. Pharm. Bioallied. Sci. 2013, 5, 245-252. [CrossRef] [PubMed]

87. Akanbi, F.S.; Yusof, N.A.; Abdullah, J.; Sulaiman, Y.; Hushiarian, R. Detection of quinoline in G. boninense-infected plants using functionalized multi-walled carbon nanotubes: A field study. Sensors 2017, 17, 1538. [CrossRef]

88. Isha, A.; Akanbi, F.S.; Yusof, N.A.; Osman, R.; Mui-Yun, W.; Abdullah, S.N.A. An NMR metabolomics approach and detection of Ganoderma boninense-infected oil palm leaves using MWCNT-based electrochemical sensor. J. Nanomater. 2019, 2019, 12. [CrossRef]

89. Rani, E.; Mohshim, S.A.; Ahmad, M.Z.; Goodacre, R.; Alang Ahmad, S.A.; Wong, L.S. Polymer pen lithography-fabricated DNA arrays for highly sensitive and selective detection of unamplified Ganoderma boninense DNA. Polymers 2019, 11, 561. [CrossRef] [PubMed]

90. Maznah, Z.; Halimah, M.; Ismail, S.; Idris, A.S. Dissipation of the fungicide hexaconazole in oil palm plantation. Environ. Sci. Pollut. Res. 2015, 22, 19648-19657. [CrossRef]

91. Muhamad, H.; Zainol, M.; Sahid, I.; Seman, I.A. Determination of hexaconazole in field samples of an oil palm plantation. Drug Test Anal. 2012, 4, 112-117. [CrossRef] [PubMed]

92. Maluin, F.N.; Hussein, M.Z.; Yusof, N.A.; Fakurazi, S.; Idris, A.S.; Hilmi, N.H.; Jeffery Daim, L.D. A potent antifungal agent for basal stem rot disease treatment in oil palms based on chitosan-dazomet nanoparticles. Int. J. Mol. Sci. 2019, 20, 2247. [CrossRef]

93. Idris, A.B.; Maizatul, S.M. Stumpt treatment with dazomet for controlling Ganoderma disease in oil palm. MPOB Inf. Ser. 2012, 107, 615-616.

94. Said, N.; Omar, D.; Nasehi, A.; Wong, M.Y. Pyraclostrobin suppressed Ganoderma basal stem rot (BSR), promoted plant growth

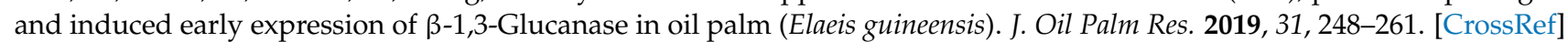

95. Yusoff, A.; Ashaari, F.H.M.; Abd Samad, M.A.; Ab Wahab, A.F.F.; Bharudin, I. Identification of soil bacteria with antifungus activity towards palm oil pathogen, Ganoderma boninense. Sains Malays. 2021, 50, 3557-3567. [CrossRef]

96. Shariffah-Muzaimah, S.A.; Idris, A.S.; Madihah, A.Z.; Dzolkhifli, O.; Kamaruzzaman, S. Isolation of actinomycetes from rhizosphere of oil palm (Elaeis guineensis Jacq.) for antagonism against Ganoderma boninense. J. Oil Palm Res. 2015, $27,19-29$.

97. Cheong, S.L.; Cheow, Y.L.; Ting, A.S.Y. Characterizing antagonistic activities and host compatibility (via simple endophyte-calli test) of endophytes as biocontrol agents of Ganoderma boninense. Biol. Control 2017, 105, 86-92. [CrossRef]

98. Angel, L.P.L.; Sundram, S.; Ping, B.T.Y.; Yusof, M.T.; Ismail, I.S. Profiling of anti-fungal activity of Trichoderma virens 159 C involved in biocontrol assay of Ganoderma boninense. J. Oil Palm Res. 2018, 30, 83-93. [CrossRef] 
99. Abdul Aziz, S.D.; Jafarah, N.F.; Sabri, S.; Abdul Wahab, M.A.; Balia Yusof, Z.N. Antifungal activity of dichloromethane and hexane extracts of four Malaysian seaweed species against Ganoderma boninense. Malays. Appl. Biol. 2019, 48, 189-196.

100. Sethuraman, A.; Janzen, F.J.; Weisrock, D.W.; Obrycki, J.J. Insights from population genomics to enhance and sustain biological control of insect pests. Insects 2020, 11, 462. [CrossRef] [PubMed]

101. Barratt, B.I.P.; Moran, V.C.; Bigler, F.; van Lenteren, J.C. The status of biological control and recommendations for improving uptake for the future. BioControl 2018, 63, 155-167. [CrossRef]

102. Shariffah-Muzaimah, S.A.; Idris, A.S.; Madihah, A.Z.; Dzolkhifli, O.; Kamaruzzaman, S.; Maizatul-Suriza, M. Characterization of Streptomyces spp. isolated from the rhizosphere of oil palm and evaluation of their ability to suppress basal stem rot disease in oil palm seedlings when applied as powder formulations in a glasshouse trial. World J. Microbiol. Biotechnol. 2017, 34, 15. [CrossRef] [PubMed]

103. Bolivar-Anillo, H.J.; González-Rodríguez, V.E.; Cantoral, J.M.; García-Sánchez, D.; Collado, I.G.; Garrido, C. Endophytic bacteria Bacillus subtilis, isolated from Zea mays, as potential biocontrol agent against Botrytis cinerea. Biology 2021, 10, 492. [CrossRef]

104. Angel, L.P.L.; Yusof, M.T.; Ismail, I.S.; Ping, B.T.Y.; Mohamed Azni, I.N.A.; Kamarudin, N.H.; Sundram, S. An in vitro study of the antifungal activity of Trichoderma virens $7 \mathrm{~b}$ and a profile of its non-polar antifungal components released against Ganoderma boninense. J. Microbiol. 2016, 54, 732-744. [CrossRef] [PubMed]

105. Alexander, A.; Abdullah, S.; Rossall, S.; Chong, K.P. Evaluation of the efficacy and mode of action of biological control for suppression of Ganoderma boninense in oil palm. Pak. J. Bot. 2017, 49, 1193-1199.

106. Lim, P.; Gansau, J.A.; Chong, K.P. Streptomyces spp. a potential biocontrol agent against Ganoderma boninense of basal stem rot. J. Oil Palm Res. 2018, 30, 265-275. [CrossRef]

107. Sujarit, K.; Pathom-aree, W.; Mori, M.; Dobashi, K.; Shiomi, K.; Lumyong, S. Streptomyces palmae CMU-AB204T, an antifungal producing-actinomycete, as a potential biocontrol agent to protect palm oil producing trees from basal stem rot disease fungus, Ganoderma boninense. Biol. Control 2020, 148, 104307. [CrossRef]

108. Sujarit, K.; Mori, M.; Dobashi, K.; Shiomi, K.; Pathom-aree, W.; Lumyong, S. New antimicrobial phenyl alkenoic acids isolated from an oil palm rhizosphere-associated actinomycete, Streptomyces palmae CMU-AB204T. Microorganisms 2020, 8, 350. [CrossRef]

109. Rebitanim, N.A.; Hanafi, M.M.; Idris, A.S.; Abdullah, S.N.A.; Mohidin, H.; Rebitanim, N.Z. GanoCare ${ }^{\circledR}$ improves oil palm growth and resistance against Ganoderma basal stem rot disease in nursery and field trials. BioMed Res. Int. 2020, 2020, 3063710. [CrossRef] [PubMed]

110. Nur Sabrina, A.; Sariah, M.; Zaharah, A. Suppression of basal stem rot disease progress in oil palm (Elaeis guineensis) after copper and calcium supplementation. Pertanika J. Trop. Agric. Sci. 2012, 35, 13-24.

111. Abdullah, S.; Ling, Y.S.; Daim, S.J.; Alexander, A.; Chong, K.P. Ganoderma boninense isolated from Sabah, Malaysia exhibits potent antibacterial activity against clinically important bacterial pathogens. Bangladesh J. Pharmacol. 2018, 13, 10-12. [CrossRef]

112. Abdullah, S.; Oh, Y.S.; Kwak, M.-K.; Chong, K. Biophysical characterization of antibacterial compounds derived from pathogenic fungi Ganoderma boninense. J Microbiol. 2021, 59, 164-174. [CrossRef]

113. Tisné, S.; Pomiès, V.; Riou, V.; Syahputra, I.; Cochard, B.; Denis, M. Identification of Ganoderma disease resistance loci using natural field infection of an oil palm multiparental population. G3 Genes Genomes Genet. 2017, 7, 1683-1692. [CrossRef] [PubMed] 